Article

\title{
Product Design for Automated Remanufacturing-A Case Study of Electric and Electronic Equipment in Sweden
}

\author{
Sasha Shahbazi ${ }^{1, *}$, Kerstin Johansen ${ }^{2}$ (D) and Erik Sundin ${ }^{3}$ (D) \\ 1 Department of Method for Product Realization, RISE IVF AB, Drottning Kristinas väg 61, \\ 11428 Stockholm, Sweden \\ 2 Department of Industrial Product Development, Production and Design, Jönköping University, \\ Gjuterigatan 5, 55111 Jönköping, Sweden; kerstin.johansen@ju.se \\ 3 Division of Environmental Technology and Management, Department of Management and Engineering, \\ Linköping University, 58183 Linköping, Sweden; erik.sundin@liu.se \\ * Correspondence: sasha.shahbazi@ri.se
}

Citation: Shahbazi, S.; Johansen, K.; Sundin, E. Product Design for Automated Remanufacturing-A Case Study of Electric and Electronic Equipment in Sweden. Sustainability 2021, 13, 9039. https://doi.org/ $10.3390 /$ su13169039

Academic Editor: Antonella Petrillo

Received: 9 July 2021

Accepted: 8 August 2021

Published: 12 August 2021

Publisher's Note: MDPI stays neutral with regard to jurisdictional claims in published maps and institutional affiliations.

Copyright: (c) 2021 by the authors. Licensee MDPI, Basel, Switzerland. This article is an open access article distributed under the terms and conditions of the Creative Commons Attribution (CC BY) license (https:/ / creativecommons.org/licenses/by/ $4.0 /)$.
Abstract: Remanufacturing is one of the main practices toward a circular economy and industrial sustainability. Remanufacturing is highly dependent on how circular products are designed and developed. Remanufacturing can also benefit from automation for efficiency, accuracy and flexibility. This paper, via a multiple case study, connects the three areas of remanufacturing, product design and automation and investigates how circular product design can facilitate automation remanufacturing processes. First, circular product design guidelines are discussed with regard to remanufacturing. Second, potential areas for automation at three remanufacturers of electric and electronic equipment are pinpointed. Finally, design guidelines are connected to the identified potential automation areas in each remanufacturing process and discussed together. According to our results, the main incentives for automating remanufacturing processes are mainly related to the work environment, efficiency and quality. In addition, several design guidelines can facilitate automated remanufacturing processes; for instance, the standardization of components, fasteners and remanufacturing tools across different models and brands can also facilitate automated remanufacturing, where products can easily and nondestructively be disassembled by a robot or a machine.

Keywords: circular economy; remanufacturing; product design; automation

\section{Introduction}

The circular economy enables industrial sustainability, and the common circular economy practices within the manufacturing industry are end-of-life strategies such as recycling and/or end-of-use strategies such as remanufacturing, repairing and reusing. It is broadly agreed upon that the majority of products and parts that are currently recirculated have not been designed for any of end-of-use strategies in the first place [1,2], while product and part circulation is heavily reliant on product design and development [3,4]. The circular economy is highly dependent on design in the very early stage of the product lifecycle, e.g., design for the disassembly of components and the segregation of different materials to facilitate the exchange of faulty components and increase recycling possibilities. Nevertheless, the majority of existing products and components that are currently being traded or used in the market have not been designed to be broken down again to the component and material levels for value retention. To be able to retrieve value from products and their components, the products need to be reused after the end-of-use in the product lifecycle, as depicted in Figure 1 below: 


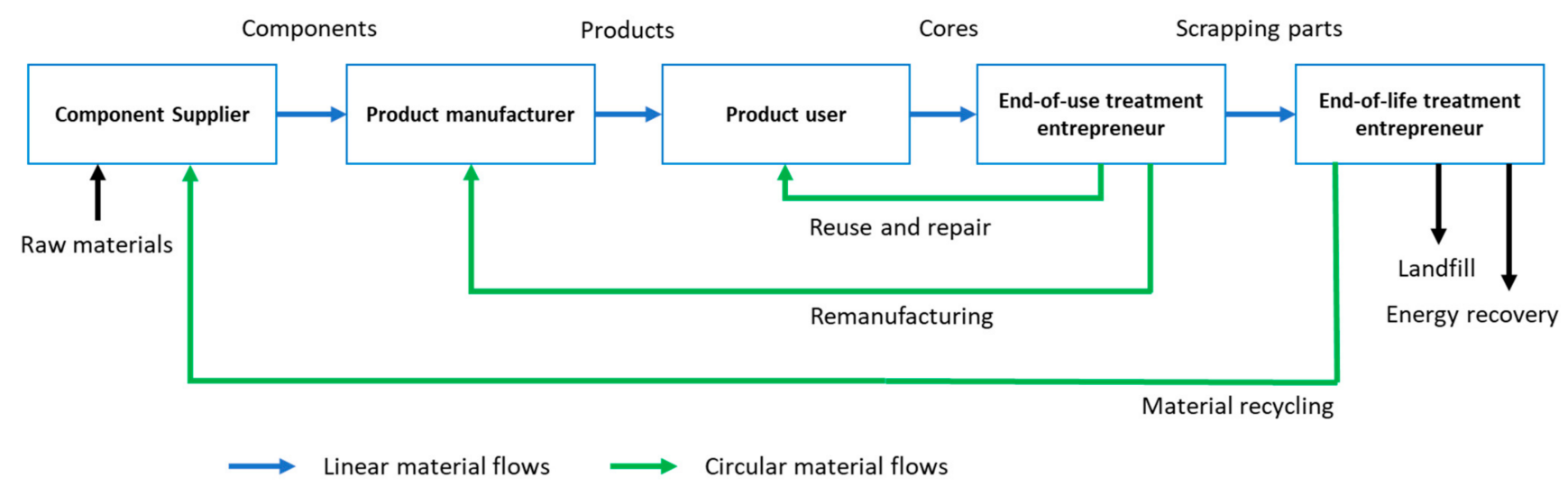

Figure 1. Product lifecycle and its actors, adapted from [5].

Several of these products or their core parts are taken back by third parties for remanufacturing or repairing to retain and recapture components' and materials' value, but the main challenges of these remanufacturing companies are low volumes, efficiency and the diversity in quality of the incoming products. One way to mitigate this challenge is a human-robot collaborative (HRC) production layout, where the robot contributes endurance, efficiency and accuracy, while the human contributes intuition, flexibility and problem solving [6]. In recent studies with technological advancements within the robot industry, remanufacturing companies have been trying to make use of automation within their process, particularly in remanufacturing electric and electronic equipment (EEE); see, e.g., [7].

Previous literature (e.g., [8-11]) has reported on the effects of product design and development on circular transition (including remanufacturing). The decisions made during product design and development substantially define the impacts of the product during its lifetime [12]. In another study, Nasr, Russell [13] assert that approximately 80\% of the sustainability performance of a product over its lifecycle is determined in the product design and development processes. On the other hand, few studies (e.g., $[7,14])$ have investigated the opportunities for the use of robots and automation in remanufacturing industries that would facilitate higher efficiency and better working conditions. Fewer studies have reported on the effect of product design on automated remanufacturing.

This paper, within the area of circular economies [8], therefore aims to investigate the connection of product design to automation in remanufacturing processes. To break down our research aim, three research questions were formulated: (1) how product design can support remanufacturing, (2) how automation can support remanufacturing processes and (3) how future products should be designed to facilitate automated remanufacturing. This paper will mainly use previously developed design guidelines [15] and an empirical study on automated remanufacturing [7]. This paper contributes to the literature and to industry to support product design and development with the increased circularity potential for automated remanufacturing.

In the following sections, we present the research methodology (Section 2). The theoretical background for remanufacturing, circular product design and automation (Section 3) is followed by an empirical study (Section 4). Afterwards, analysis and discussion (Section 5) along with a conclusion and future work section (Section 6) are presented.

\section{Methodology}

This paper aims to investigate the connection of product design to automation in remanufacturing processes. The paper is mainly based on an empirical study, although a structured literature search on product design, automation, remanufacturing and their combination was carried out. The literature selection incorporated the keywords "product design", "product development", "automation", "remanufacturing", "repair" and combinations thereof. This search was then extended through a qualitative upstream and 
downstream search of the references in the selected articles. The literature selection was based on reviewing abstracts and reading full-text articles.

For the empirical study, a multiple case study of three remanufacturing companies was designed and conducted to fulfill the aim of this study. With a limited understanding of product design and its connection to automated repair and remanufacturing processes, the adopted multiple case study methodology was appropriate [16] to fulfil the research aim. The studied companies are mainly SMEs within the electrical and electronic equipment industry located in Sweden and vary in terms of plant size, remanufactured products, volume, product complexity and technical remanufacturing processes; see the overview of companies in Table 1. Although these companies have technical remanufacturing processes, their repair and remanufacturing processes generally include inspecting incoming products, disassembling, cleaning (at several stages), reprocessing (any activities to make the product or component functional again, e.g., exchanging or repairing parts), reassembling, final testing and packaging before being sent to customers. The studied companies have not implemented automation solutions in their current remanufacturing processes, and the companies' participation in our study was therefore mainly based on their intention to improve and evaluate the potential automation of their repair and remanufacturing processes in a common research project.

Table 1. Overview of companies studied.

\begin{tabular}{cccc}
\hline Company & Product & Type of Remanufacturer & Experience \\
\hline Company A & IT equipment & Independent & 21 years \\
\hline Company B & Photocopiers & Contracted & 36 years \\
\hline Company C & Car electronics & Contracted & 43 years \\
\hline
\end{tabular}

The empirical data collection for this study was performed through multiple sources of evidence, as suggested by Yin [16], including document review, participant observation at all case companies, semi-structured interviews and focus group workshops for follow-up discussions. The document reviews, as the first step in the empirical data collection, were carried out to obtain basic insight about companies-their overall strategies, business models and environmental targets. The participant observations included visiting companies and discussing issues related to the general process of their remanufacturing, product types, potential automation in their remanufacturing processes, and general challenges and opportunities in implementing automation for remanufacturing and repair processes. Document review and participant observations were used as a basis for the main data collection, i.e., semi-structured interviews. The semi-structured interviews were based on predefined questions and open dialog where the interviewees had the opportunity to further explain his/her answers with back-and-forth discussions. Each semi-structured interview lasted approximately one hour and incorporated the following main questions: (1) Step A1: How can product design facilitate the process of remanufacturing? For example, making it more efficient, faster or cheaper. (2) Step A2: How can automation facilitate the process of remanufacturing? For example, making it more efficient, faster or cheaper (3) Steps B1 and B2: which circular product design guidelines from [15] are in place right now and should be in future? Focus group workshops were structured for specific discussion and multidisciplinary idea presentation on challenges related to automation and product design at companies.

Throughout the data collection and analysis, consistency between the cases was maintained through the constant comparison and review of the results with each other and with theoretical data. In addition, the collected empirical data were simplified, organized and interpreted following the recommendation by [17]. Figure 2 illustrates the different pieces of our study and their connection. 


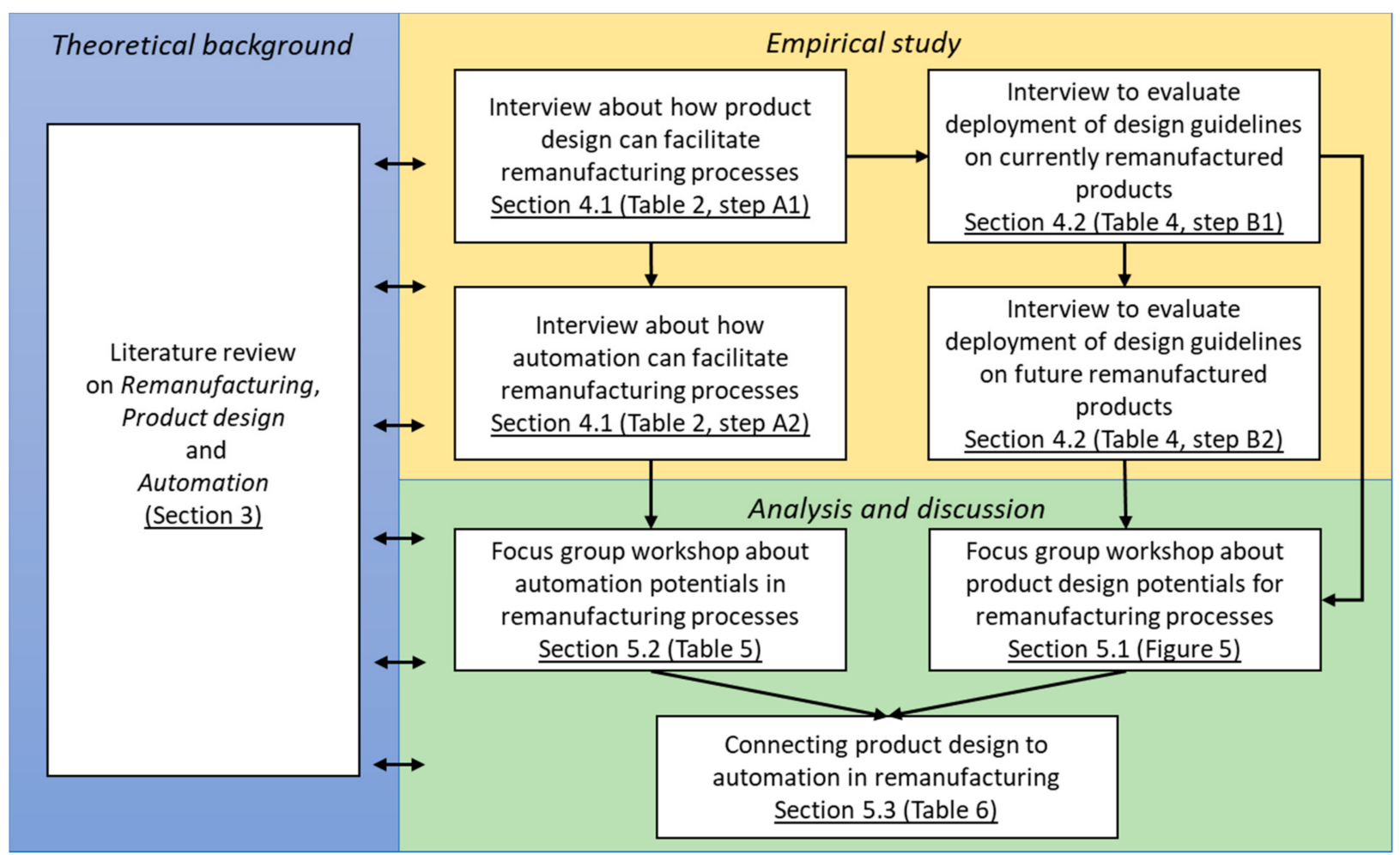

Figure 2. Summary of the research method.

\section{Theoretical Background}

\subsection{Remanufacturing}

Reverse logistics and products' end-of-use scenarios have been on the rise lately, with several different strategies trying to recirculate products and components. These strategies include repair/maintenance and upgrading with the aim of extending the existing lifecycles as well as reuse, refurbishment, remanufacturing and repurposing with the aim of extending the lifecycle to new lifecycles [18]. Among these strategies, remanufacturing has been more recognized and researched, mainly because it has a broader scope and more applicability to a variety of products. In addition, there is a very thin line between the definitions of these strategies, and if one were to sum them up into a single strategy, it would be remanufacturing. Remanufacturing can be defined as "an industrial process whereby products, referred to as cores, are restored to useful life. During this process, the core passes through a number of remanufacturing operations, e.g., inspection, disassembly, part reprocessing, reassembly and testing, to ensure that it meets the desired product standards [19]. The remanufactured product might have equivalent or higher performance and functionality, and it can be sold to or used by the same user or a new user. Full warranties and guarantees are given in remanufacturing.

For remanufacturing, it is also important to have a lifecycle perspective, meaning that information and data in the form of feedback and guidelines can be fed into product design and development. Lindkvist Haziri and Sundin [20] developed a framework called the remanufacturing information feedback framework (RIFF), which is a method for strategically outlining and practically implementing feedback from the remanufacturing to the design departments. The feedback information (see Figure 3) could be used to design products and components in a way that makes remanufacturing execution much easier, faster, efficient and more inexpensive. 


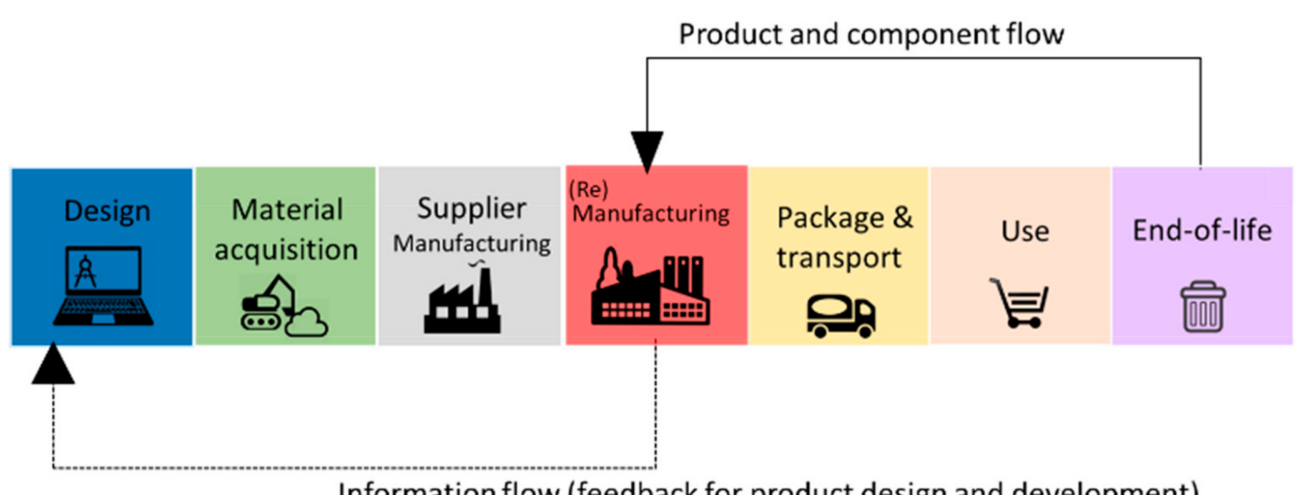

Information flow (feedback for product design and development)

Figure 3. Simplified repair and remanufacturing flows.

Past literature (e.g., [21-25]) has identified several barriers for remanufacturing that include the following: (1) Sufficient volume of the same kind of product is required to be able to run a manufacturing facility. Therefore, a consistent and smooth flow of incoming products for remanufacturing is vital. (2) The same incoming products are in different shapes and form, i.e., different stages of their lifecycle, and hence require different reprocessing. (3) Most of the existing products on the market were not designed for remanufacturing and repair but to be disposed of after a certain period of use. (4) Infrastructure is required for product collection, while the collection and transportation of incoming products over great distances might not be environmentally and economically beneficial. (5) There are some levels of insecurity about the quality of the products or components that are coming back for remanufacturing. Consumers might mistrust remanufactured products, thinking they are not as functional as new ones. (6) Legal aspects, regulations and standards might be problems that require adjusting products and offerings to meet new requirements, such as for chemicals. (7) The fear that sales of the company's new products will decrease and that the loss of these sales will be greater than the profit from the selling of remanufactured products, known as market cannibalization. (8) Keeping old products in use has the risk of preventing new, more energy-efficient products from entering the market.

According to [26], end-of-use scenarios can be better managed considering two aspects: improving the ease of disassembly (design) and improving disassembly technologies (automation). Both these aspects are discussed below.

\subsection{Product Design and Development}

Recent product design and development have been inspired by several frameworks, such as design for X [27,28], design for the environment [29,30], design for disassembly [31,32], ecodesign [33-35] and design for recycling [36,37]. Previous studies have also focused on the design of remanufacturing frameworks $[11,38]$. Product design and development for remanufacturing aims to dismantle and reassemble a product nondestructively, as well as interchange components and modular design where the core components can easily and quickly be repaired or replaced. Therefore, design for remanufacturing can facilitate and overcome the first three abovementioned barriers in Section 3.1. Past literature (e.g., [15,39]) has developed several design guidelines for remanufacturing, which include the following:

- Make exchange and faulty components easily accessible

- Make it easy to inspect the product and its components

- Make it easy to clean the product and its components

- Make it easy to disassemble the product and its components nondestructively

- Use durable and robust components and materials, e.g., corrosion-resistance

- Use fasteners and connectors that can be easily opened and closed multiple times

- Design with standardized fasteners and components across different products and models

- Design to use standard tools across different products and models

- Make spare parts and exchange components easily available 
- Adapt a modular design

- Investigate how current and upcoming laws and regulations affect product design

- Design the product with a focus on functionality and upgradability

Some of these guidelines are not technical but must still be considered in the product design phase to facilitate remanufacturing processes.

\subsection{Automation}

Automation refers to any technological improvement in carrying out the remanufacturing processes with reduced human intervention (e.g., using robots, automated guided vehicles (AGVs), computerization or software); however, in this study, we discuss robotization and using a robot arm to facilitate the remanufacturing processes.

Remanufacturing demands an understanding of the need for managing the differences in incoming material/products [7], particularly for products that have not been designed for remanufacturing. This is closely connected to managing responsiveness in a production system, where it is important to understand efficiency and flexibility-machine, process, product, routing, volume, expansion, operation and production [40]. Such a challenge could be facilitated through design approaches for developing a production system that can integrate robots into the operation to easily support flexibility and efficiency demands, including managing fast changes between products [41]. However, for assembly systems (which are comparable with disassembly and reassembly systems), automation can be considered to be important in managing the efficiency and flexibility that are induced by various product types or the diversity in the quality of the incoming products [42,43]. As a result, the advantages of automation in remanufacturing processes are conclusive [7].

One way to manage the abovementioned challenges is to design an HRC layout, where the robot contributes endurance, efficiency and accuracy, while the human contributes intuition, flexibility and problem solving $[6,43]$. However, the design of a collaborative workspace where an operator shares a workspace and, if applicable, a work task with a robot demands a risk assessment. Gopinath and Johansen [44] argue that a risk assessment can support the design of a layout by identifying monotonous and hazardous operations that a robot can be allocated for and the operations that demand more flexible and cognitive skills that the operators can perform. According to Chen et al. [45], it is possible to develop an HRC layout where the robot performs all unscrewing while disassembling electrical batteries for vehicles, although a drawback is the time consumption for identifying the location of fasteners. Huang et al. [43] conclude that an effective strategy in disassembly is to utilize the combination of humans and robots in a semi-automated layout to increase flexibility and productivity, including reducing capital costs. Thus, automation solutions in a remanufacturing process are possible if they are safe, cost-efficient and can balance the collaboration between humans and robots utilizing their different strengths in a flexible and productive way. According to Bauer et al. [46], there are five various levels of HRC, including cell, coexistence, synchronized, cooperation and collaboration. The cell configuration is a standard industrial robot in a cage example where the human worker cannot interact with the robot. The other four configurations have different levels of interaction between a robot and a human worker.

\section{Empirical Study}

The case studies at the companies were performed with two main steps and two substeps each. Step A addressed remanufacturing processes and how product design (A1) and automation (A2) can facilitate a specific remanufacturing process. It is worth emphasizing that the general remanufacturing processes within these companies are largely the same including inspection, disassembly, cleaning, reprocessing, reassembly and testing, although the technical details are different (e.g., what to clean and how to clean). Step B addressed the evaluation of circular design guidelines [15] and their deployment for current remanufactured products (B1) and future products (B2). 


\subsection{Step A: Remanufacturing Processes-Connection to Product Design and Automation}

In step A of the empirical data collection, the companies were interviewed to determine whether product design and automation could facilitate their own remanufacturing with regard to products they currently remanufacture and processes they currently have. In addition, the collected data from the interviews were combined with the direct observations and evaluation of potential areas for automation in focus group workshops. Table 2 summarizes the answers from interviewees with regard to the facilitation of remanufacturing through product design (A1) and automation (A2).

Table 2. Remanufacturing processes' connection to product design and automation ( $\mathrm{Y}=\mathrm{yes}$, to a large extent; $\mathrm{y}=$ yes, to some extent; $\mathrm{N}=$ no impact).

\begin{tabular}{ccccccc}
\hline \multirow{2}{*}{$\begin{array}{c}\text { Remanufacturing } \\
\text { Processes }\end{array}$} & \multicolumn{3}{c}{ If Product Design Facilitates? (A1) } & \multicolumn{3}{c}{ If Automation Facilitates? (A2) } \\
\cline { 2 - 6 } & \multicolumn{3}{c}{ Companies } & Companies \\
\cline { 2 - 6 } & A & B & C & A & B & C \\
\hline Inspection & $\mathrm{Y}$ & $\mathrm{Y}$ & $\mathrm{y}$ & $\mathrm{y}$ & $\mathrm{y}$ & $\mathrm{y}$ \\
Disassembly & $\mathrm{Y}$ & $\mathrm{Y}$ & $\mathrm{Y}$ & $\mathrm{y}$ & $\mathrm{y}$ & $\mathrm{Y}$ \\
Cleaning & $\mathrm{Y}$ & $\mathrm{Y}$ & $\mathrm{y}$ & $\mathrm{y}$ & $\mathrm{y}$ & $\mathrm{y}$ \\
Reprocess & $\mathrm{y}$ & $\mathrm{y}$ & $\mathrm{y}$ & $\mathrm{y}$ & $\mathrm{y}$ & $\mathrm{Y}$ \\
Reassembly & $\mathrm{Y}$ & $\mathrm{Y}$ & $\mathrm{Y}$ & $\mathrm{y}$ & $\mathrm{y}$ & $\mathrm{Y}$ \\
Testing & $\mathrm{N}$ & $\mathrm{N}$ & $\mathrm{N}$ & $\mathrm{N}$ & $\mathrm{N}$ & $\mathrm{N}$ \\
\hline
\end{tabular}

\subsection{Step B: Circular Design Guidelines-Connection to Current and Future Products}

The generic product design guidelines for remanufacturing have been mentioned in the bullet points in Section 3.2. In Step B of our empirical study, the whole collection of generic guidelines for circular product design was assessed and discussed, although the main focus remained on design for remanufacturing. The reason behind this decision was to see if interviewees/industrial practitioners might have different opinions with regard to design guidelines for remanufacturing. For instance, some extra guidelines could be related to their specific products, while some other guidelines could be irrelevant to another product in another company. Table 3 presents the generic circular design guidelines with a short description of each and an indication of their relevance to only remanufacturing.

Table 3. Generic circular design guidelines (adapted and modified from [15]).

\begin{tabular}{|c|c|c|}
\hline Design Guidelines & Brief Description & $\begin{array}{l}\text { Relevancy to } \\
\text { Remanufacturing }\end{array}$ \\
\hline $\begin{array}{l}\text { (1) Make exchanging and faulty } \\
\text { components easily accessible }\end{array}$ & $\begin{array}{l}\text { Make disassembly points and components subject to break, } \\
\text { wear or fail easily accessible and preferably from one side }\end{array}$ & ${ }^{* * *}$ very relevant \\
\hline $\begin{array}{l}\text { (2) Make it easy to inspect the product } \\
\text { and its components }\end{array}$ & $\begin{array}{l}\text { Make it easy and safe to inspect the product and } \\
\text { components, particularly exchanging components. Use } \\
\text { indications and repair manuals for testing and inspections }\end{array}$ & $* * *$ very relevant \\
\hline $\begin{array}{l}\text { (3) Make it easy to clean the product } \\
\text { and its components }\end{array}$ & $\begin{array}{l}\text { Avoid shapes and areas that dirt might collect in such as } \\
\text { small holes, nooks, grooves and sharp edges. Select } \\
\text { materials that are easy to clean. All components should be } \\
\text { able to withstand the same chemicals, mechanical cleaning } \\
\text { processes, and temperatures }\end{array}$ & $* * *$ very relevant \\
\hline $\begin{array}{l}\text { (4) Make it easy to disassemble the } \\
\text { product and its components } \\
\text { nondestructively }\end{array}$ & $\begin{array}{l}\text { Make it easy to open and dismount in a nondestructive way. } \\
\text { Use less glue and adhesives. Ensure the robustness and } \\
\text { wear resistance of fasteners. Allow disassembly from one } \\
\text { side. Provide manuals }\end{array}$ & $* * *$ very relevant \\
\hline
\end{tabular}


Table 3. Cont.

\section{Design Guidelines}

(5) Use durable and robust components and materials

(6) Use fasteners and connectors that can be easily opened and closed multiple times

(7) Design with standardized fasteners and components across different products and models

(8) Design to use standard tools across different products and models

(9) Make spare parts and exchanging components easily available

(10) Adapt a modular design

(11) Investigate current and upcoming laws and regulations

(12) Focus mainly on functionality and quality performance

(13) Make it easy to identify the materials and relevant information

(14) Consider the toxicity and other environmental aspects of the materials

(15) Provide repair manuals and documentation

(16) Think about activity support in the operational stage

\section{Brief Description}

Relevancy to Remanufacturing

Choose durable, corrosion-resistant and robust components and materials with a long lifespan. The lifespan of the different parts should be recognizable with indicators for $\quad$ *** very relevant wear. Avoid materials that might lose strength, get brittle or get discolored

Minimize the number of connectors and fasteners. Ensure the robustness and wear resistance of fasteners. Prioritize latch, snaps, clips, bolts and screws over welding, rivets, folding, staples and gluing, which make fasteners more difficult to demount

The compatibility and exchangeability of components are required across other models and products, e.g., same type $\quad$ *** very relevant and size of screws

The compatibility and adaptability of tools are required across other models and products, e.g., same type and size $\quad{ }^{* * *}$ very relevant of screwdriver to dismantle

Exchanging components of products must be easy to find on the market and preferably be inexpensive or 3D-printable $\quad * * *$ very relevant with additive manufacturing technologies

Divide the product into different modules and put all of the components that need to be exchanged or upgraded into $\quad * * *$ very relevant one single module, thus lowering the effort

Comply with applicable laws and regulations such as those regarding hazardous materials or chemicals that are or will $\quad * * *$ very relevant be thought to be harmful and might be banned

Focus mainly on functionality and quality performance, as age, make and model are less important as long as the $\quad{ }^{* * *}$ very relevant quality-performance is delivered. Ensure plan upgradability

Create a system for the identification of the individual components by, for example, RFID, barcode, tag or QR-code. Provide additional information about the product regarding the material's content, the material's age, the number of ** relevant times recycled, the additives used, the guide to component separation and the process for the recycling.

Use materials that that do not threaten biodiversity and do not contain hazardous chemicals. Select materials that do not degenerate during multiple lifecycles. Select materials with verified reliability. Avoid materials that lose strength, get brittle or get discolored

Provide user-friendly repair manuals and documentation on how to repair, upgrade, etc. with signs on how to open the $\quad * *$ relevant product and exchange components

Think about activity support during the operational stage of the product/service to make the system run as efficiently as possible, e.g., supplying replacement materials,

** relevant maintenance services, repair and control in post-use 
Table 3. Cont.

\section{Design Guidelines}

\section{Brief Description}

Relevancy to Remanufacturing
(17) Focus to fulfill the customer's requirements and value creation
Develop a close relationship with the customer to understand their requirements, develop capabilities accordingly and adjust personalized services with individual access. The service design cycle is continuously $\quad{ }^{* *}$ relevant repeated and improved to be able to adapt to various human factors and requirements

Think about the effects that time and fashion will have on your product. Simplicity, timeless design and compatibility can be some ways to give the product longevity (e.g., a USB device)

(18) Consider timeless design, emotional attachment and compatibility

(19) Treat remanufacturing waste appropriately

Think about the type and amount of waste generated in remanufacturing processes. What segment and fraction of those broken/exchanging components can be separated to be able to facilitate recycling?

IoT and digitalization enable data collection about the usage behavior and product performance throughout a product's lifecycle. This aids in the discovery of latent design errors and in the understanding of what components are going to

* can be relevant fail and when, such that repair and maintenance can be planned with minimum effect on the products' performance

Reduce the use of materials that are limited in quantities such as tin and precious metals, and use more renewable * can be relevant and bio-based materials, if possible

Choose materials that have a high recycling rate and an available recycling technology and market. Increase the materials' compatibility so that only one recycling method is * can be relevant needed. Increase the proportion of recycled materials in your product and use less virgin raw materials

(22) Design using recyclable and secondary (recycled) materials

Favor manufacturing processes, machines and equipment that use less energy and materials, generate less waste and discharges less into the air and water. Select machines and equipment that require less frequent maintenance and

* can be relevant processes, machines and equipment cleaning and possess a good working environment and ergonomic value

Design the product with reduced energy consumption by materials to facilitate shredding, regeneration and recycling. using renewable and clean energy. Select production processes with high energy efficiency to reduce energy consumption. Consider the energy recovery of biological nutrients

Minimize the number of different incompatible or dissimilar Avoid molding and fusing incompatible materials. Avoid multi-materials and composites
(25) Minimize the number of different incompatible or dissimilar materials
(24) Design for reduced energy consumption and usage of renewable energy

Table 4 summarizes the answers from interviewees with regard to the deployment of circular design guidelines for current remanufactured products (B1) and future products (B2). The empirical data collection in this step questioned whether the generic circular guidelines (Table 3) had been deployed for remanufactured products and how those guidelines should be deployed for future products for remanufacturing. During the interview, the focus maintained on the companies' own remanufacturing processes and remanufactured products. 
Table 4. Circular design guidelines deployment for our three remanufacturing companies regarding current and future products $(Y=$ Yes, to a large extent; $y=$ Yes, to some extent; $N$ = Not deployed; - = irrelevant or I don't know).

\begin{tabular}{|c|c|c|c|c|c|c|}
\hline \multirow[b]{2}{*}{ Generic Design Guidelines } & \multicolumn{2}{|c|}{ Company A } & \multicolumn{2}{|c|}{ Company B } & \multicolumn{2}{|c|}{ Company C } \\
\hline & $\begin{array}{l}\text { Current } \\
\text { Products }\end{array}$ & $\begin{array}{l}\text { Future } \\
\text { Products }\end{array}$ & $\begin{array}{l}\text { Current } \\
\text { Products }\end{array}$ & $\begin{array}{l}\text { Future } \\
\text { Products }\end{array}$ & $\begin{array}{l}\text { Current } \\
\text { Products }\end{array}$ & $\begin{array}{l}\text { Future } \\
\text { Products }\end{array}$ \\
\hline (1) Make exchanging and faulty components easily accessible & $\mathrm{N}$ & $\mathrm{Y}$ & $\mathrm{y}$ & $\mathrm{Y}$ & $\mathrm{y}$ & $\mathrm{Y}$ \\
\hline (2) Make it easy to inspect the product and its components & $\mathrm{N}$ & $\mathrm{Y}$ & $\mathrm{y}$ & $\mathrm{Y}$ & $\mathrm{N}$ & $\mathrm{y}$ \\
\hline (3) Make it easy to clean the product and its components & $\mathrm{y}$ & $\mathrm{Y}$ & $\mathrm{y}$ & $\mathrm{Y}$ & $\mathrm{N}$ & $\mathrm{y}$ \\
\hline $\begin{array}{l}\text { (4) Make it easy to disassemble the product and its components } \\
\text { nondestructively }\end{array}$ & $\mathrm{Y}$ & Y & Y & $\mathrm{Y}$ & $\mathrm{N}$ & Y \\
\hline (5) Use durable and robust components and materials & $\mathrm{Y}$ & $\mathrm{Y}$ & $\mathrm{y}$ & $\mathrm{y}$ & $\mathrm{Y}$ & $\mathrm{Y}$ \\
\hline $\begin{array}{l}\text { (6) Use fasteners and connectors that can be easily opened and } \\
\text { closed multiple times }\end{array}$ & $\mathrm{y}$ & Y & $\mathrm{y}$ & Y & $\mathrm{y}$ & Y \\
\hline $\begin{array}{l}\text { (7) Design with standardized fasteners and components across } \\
\text { different products and models }\end{array}$ & $\mathrm{y}$ & Y & $\mathrm{y}$ & Y & $\mathrm{N}$ & Y \\
\hline $\begin{array}{l}\text { (8) Design to use standard tools across different products } \\
\text { and models }\end{array}$ & $\mathrm{N}$ & Y & $\mathrm{y}$ & Y & $\mathrm{y}$ & Y \\
\hline (9) Make spare parts and exchanging components easily available & $\mathrm{y}$ & $\mathrm{Y}$ & $\mathrm{y}$ & $\mathrm{Y}$ & $\mathrm{y}$ & $\mathrm{Y}$ \\
\hline (10) Adapt a modular design & $\mathrm{N}$ & Y & $\mathrm{y}$ & Y & $\mathrm{y}$ & Y \\
\hline (11) Investigate current and upcoming laws and regulations & $\mathrm{y}$ & $\mathrm{y}$ & $\mathrm{y}$ & $\mathrm{y}$ & $\mathrm{y}$ & $\mathrm{y}$ \\
\hline (12) Focus mainly on functionality and quality performance & $\mathrm{y}$ & $\mathrm{y}$ & $\mathrm{y}$ & $\mathrm{y}$ & $\mathrm{y}$ & $\mathrm{y}$ \\
\hline (13) Make it easy to identify the materials and relevant information & $\mathrm{N}$ & $\mathrm{y}$ & $\mathrm{y}$ & $\mathrm{y}$ & $\mathrm{N}$ & $\mathrm{y}$ \\
\hline (14) Consider toxicity and other environmental aspects of materials & $\mathrm{y}$ & $\mathrm{y}$ & $\mathrm{y}$ & $\mathrm{y}$ & $\mathrm{y}$ & $\mathrm{y}$ \\
\hline (15) Provide repair manuals and documentation & $\mathrm{N}$ & $\mathrm{y}$ & $\mathrm{N}$ & Y & $\mathrm{y}$ & Y \\
\hline (16) Think about activity support in the operational stage & $\mathrm{y}$ & $\mathrm{y}$ & $\mathrm{y}$ & $\mathrm{y}$ & - & - \\
\hline (17) Focus to fulfill the customer's requirements and value creation & - & - & $\mathrm{y}$ & $\mathrm{y}$ & - & - \\
\hline $\begin{array}{l}\text { (18) Consider timeless design, emotional attachment } \\
\text { and compatibility }\end{array}$ & - & - & - & - & - & - \\
\hline (19) Treat remanufacturing waste appropriately & Y & Y & Y & Y & Y & Y \\
\hline (20) Try to use digitalization, ICT and IoT solutions & $\mathrm{N}$ & $\mathrm{y}$ & $\mathrm{y}$ & $\mathrm{y}$ & $\mathrm{N}$ & $\mathrm{y}$ \\
\hline (21) Design using renewable materials & $\mathrm{N}$ & $\mathrm{y}$ & $\mathrm{N}$ & $\mathrm{y}$ & $\mathrm{N}$ & $\mathrm{N}$ \\
\hline (22) Design using recyclable and secondary (recycled) materials & $\mathrm{N}$ & $\mathrm{y}$ & $\mathrm{N}$ & $\mathrm{y}$ & $\mathrm{N}$ & $\mathrm{y}$ \\
\hline (23) Favor cleaner production, processes, machines and equipment & $\mathrm{y}$ & $\mathrm{y}$ & $\mathrm{y}$ & $\mathrm{y}$ & $\mathrm{y}$ & $\mathrm{Y}$ \\
\hline $\begin{array}{l}\text { (24) Design for reduced energy consumption and usage of } \\
\text { renewable energy }\end{array}$ & $\mathrm{y}$ & $\mathrm{y}$ & $\mathrm{y}$ & $\mathrm{y}$ & $\mathrm{y}$ & $\mathrm{y}$ \\
\hline $\begin{array}{l}\text { (25) Minimize the number of different incompatible or } \\
\text { dissimilar materials }\end{array}$ & $\mathrm{y}$ & $\mathrm{y}$ & $\mathrm{y}$ & $\mathrm{y}$ & $\mathrm{N}$ & $\mathrm{y}$ \\
\hline
\end{tabular}

The guidelines "favor cleaner production, processes, machines and equipment" and "treat production (pre-consumer) wastes appropriately" link to remanufacturing processes and not to the original equipment manufacturer (OEM).

\section{Analysis and Discussion}

\subsection{Product Design Potentials for Remanufacturing Processes}

According to our study (see Table 2), product design can influence all remanufacturing processes except for testing. Generally, it was perceived that the inspection of retrieved products for remanufacturing is not always an easy task and requires manual and subjective evaluation (visual eye inspection) and personal judgment. However, products and components can be standardized [47] to facilitate inspection across different products and models. Products can also be designed in a way that inspection (the identification and verification of faulty components) is carried out without requiring other steps such as disassembly and cleaning. For example, inspection points and testing components 
should be marked and should be easily accessible. Product design can also influence disassembly and reassembly processes of remanufacturing [31,32] where products can be easily and nondestructively dismantled. The standardization of constructions and fasteners is helpful to avoid any critical security conditions. This requires the robustness and wear resistance of product parts and fasteners [48] as well as the avoidance of using glue and adhesives [29], which make fasteners more difficult to demount. Latches, snaps and clips are normally preferred over screws and bolts for time efficiency reasons, while bolts and screws are preferred over welding, rivets, folding and staples. Screw heads such as the hexhead cross drive, slotted internal Torx and hexhead internal Torx are good choices for multiple disassembly and reassembly. Furthermore, there are imperative product design improvements for the cleaning process of remanufacturing, particularly the cleaning of internal parts. This includes design for wear resistance to withstand liquid and chemicals, temperatures, detergents and mechanical cleaning tools. The cleaning areas should be accessible, while small holes, nooks, grooves, sharp edges and thresholds that capture dirt must be avoided. Reprocessing is the heart of remanufacturing and for EEE products mainly includes exchanging faulty components. As a result, exchanging/faulty components must be easily accessible, preferably from one side. The standardization of components and tools [47] across different products and models plays an essential role in the efficiency of this process. Modular design [49] is also critical here where parts that need to be exchanged or repaired should be placed into one single module, thus lowering the effort needed to repair/exchange parts. Those parts that will not continue the journey to the next new lifecycle have to be designed for recycling [36,37].

The analysis process of Table 4 was carried out in several steps. In the first step, "design guideline deployment to a large extent" (marked with $\mathrm{Y}$ in the future column) was only reviewed. Indicated by all three companies, eight design guidelines were considered to be absolutely vital to be deployed in future products to ease remanufacturing. These design guidelines include 1, 4, 6, 7, 8, 9, 10 and 19. Moreover, guidelines 2, 3, 5 and 15 were considered to be absolutely vital to be deployed on future remanufactured products by at least two companies. However, as indicated by at least two companies, guidelines 4, 5 and 19 are already being deployed for current remanufactured products.

Conclusions from the first step:

(1) Designing products to be easily and nondestructively disassembled is vital for future remanufacturing; however, currently, remanufactured products can already be disassembled easily to a large extent.

(2) Designing products and components with durable and robust materials is vital for future remanufacturing; however, currently remanufactured products are already robust to a large extent, i.e., they do not break with disassembly and reassembly.

(3) Treating remanufacturing waste (faulty/broken/exchanging components) appropriately is vital for future remanufacturing; however, waste from remanufacturing processes is already being handled correctly.

(4) Product design and development improvement to facilitate remanufacturing processes in the future mainly lies in design for accessibility, design for ease of cleaning, inspection and disassembly, the use of durable and robust materials and components, design improvements on fasteners and connectors, design standardization of components and tools, the adoption of modular design and the availability of spare parts and repair manuals. In addition, the exchanging component within the remanufacturing processes should be handled correctly for a proper end-of-life scenario.

In the second step, the design guidelines with improvement potential (meaning $\mathrm{N}$ $>\mathrm{y}, \mathrm{N}->\mathrm{Y}$ and $\mathrm{y}->\mathrm{Y}$ ) for future remanufactured products were reviewed. There was a consensus among all three companies only for guidelines $6(\mathrm{y}->\mathrm{Y}), 9(\mathrm{y}->\mathrm{Y})$ and 22 $(\mathrm{N}->\mathrm{y})$. All companies indicated that guidelines 5, 11, 12, 14, 16, 17, 18, 19 and 24 were unchanged for current and future products, which means that, according to the companies, either no improvement in future remanufactured products is required or that the guidelines are irrelevant to the studied remanufacturing companies (mainly due to their product type). 
Two out of three companies indicated that guidelines 4, 23 and 25 were unchanged for current and future products.

Conclusions from the second step:

(1) Some guidelines, including using recyclable and recycled material, using renewable material, using digitalized solution and making it easy to identify the material, are not deployed for currently remanufactured products at the studied companies. However, some improvements are required for the future.

(2) The guidelines for designing to ease inspection and providing repair manuals received completely diverse answers from each company (i.e., N-> y, N- > Y and y- > Y). Nevertheless, answers indicate improvement requirements for the future.

(3) Several guidelines had been deployed to some extent for currently remanufactured products at the companies studied; however, the deployments need to be much better in the future. These guidelines include design for accessibility, design for ease of cleaning, design for standardized components and tools, design improvements on fasteners and connectors, the availability of spare parts, and the adoption of modular design.

In the third step, the guidelines' relevancy to remanufacturing (third column in Table 3) was connected to the analysis steps 1 and 2 to understand how the remanufacturing design guidelines' relevancy/importance connects to deployments (Table 4), i.e., Tables 3 and 4 were analyzed together. Based on the two tables and criteria (importance from Table 3 and deployment from Table 4), a matrix (Figure 4) for the remanufacturing design guidelines was developed to determine the level of potential. The left side of the matrix represents guideline relevance to remanufacturing (from Table 3 ), where 3 is very relevant, 2 is relevant, 1 can be relevant and 0 is irrelevant. The top row of the matrix represents our empirical results related to design guideline deployment (Table 4), where - indicates irrelevant; $Y-Y$ indicates that the guidelines are to a large extent deployed for current remanufactured products and should be kept deployed for future products; $y$-y indicates that the guidelines are deployed to some extent for current remanufactured products and should remain the same for future products; $\mathrm{y}-\mathrm{Y}$ indicates that the guidelines are deployed to some extent for current remanufactured products but should be deployed to a larger extent for future products; $\mathrm{N}-\mathrm{y}$ indicates that the guidelines are not deployed for current remanufactured products but should be deployed to some extent for future products; and N-Y indicates that the guidelines are not deployed for current remanufactured products but should be deployed to a larger extent for future products.

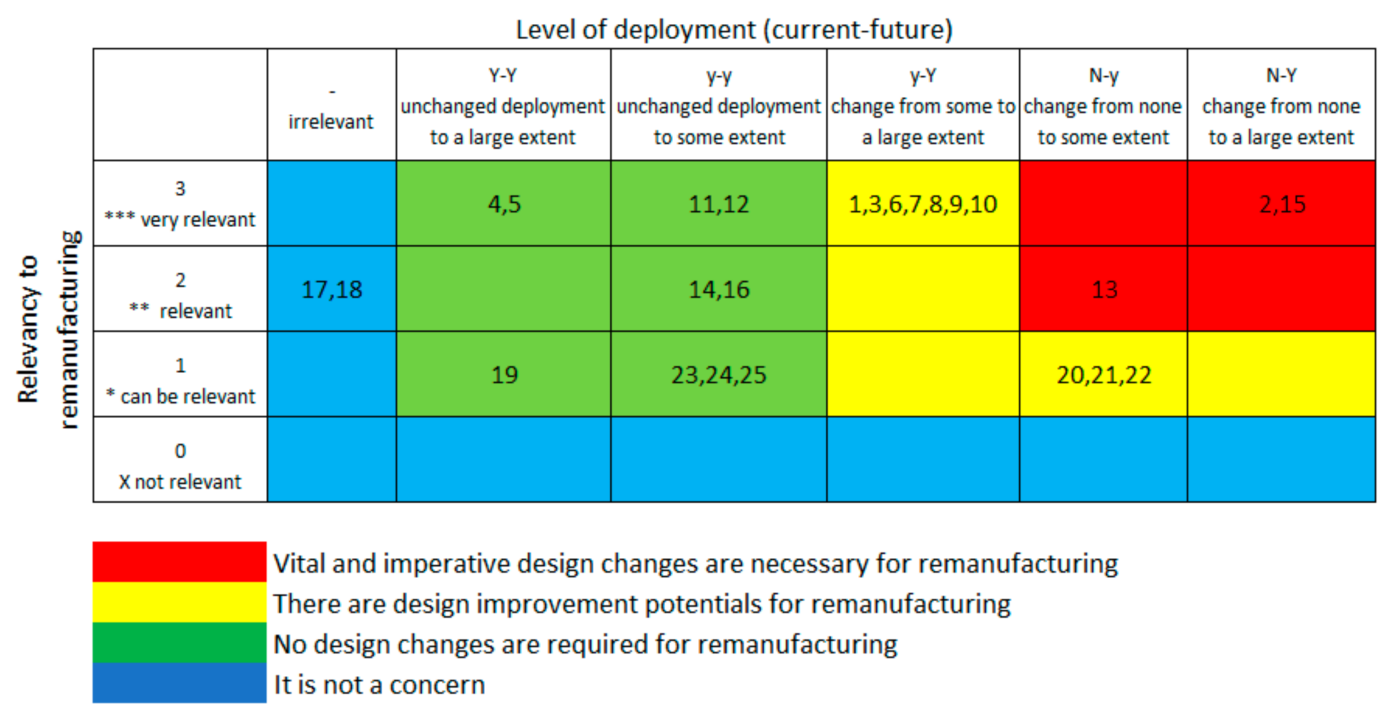

Figure 4. Design guideline potential matrix (figures refers to the guideline numbers in Table 4). 
Conclusions from the third step:

(1) Some design guidelines (in the red area) are vital and imperative to facilitate remanufacturing in the future, and these guidelines are not currently being deployed at all. Thus, these design guidelines need to be prioritized for future product development. These guidelines include making it easy to inspect, making it easy to identify materials and relevant information and providing repair manuals.

(2) There are some potential product design improvements (in the yellow area) that can facilitate remanufacturing in the future. These potential product design improvements are either currently deployed to some extent but can be applied to a larger extent or they are not deployed at all but need to be.

(3) There are several design guidelines (in the green area) that are currently deployed to the right extent and already facilitate remanufacturing. Hence, no product design changes are required now.

(4) Timeless design and the adoption of customer requirements were not found to be a concern to the facilitation of remanufacturing at the studied companies. This can be basically justified by the product type at the studied remanufacturing companies as well as the absence of OEMs in our study.

\subsection{Automation Potential in the Remanufacturing Processes}

According to our previous study [7], there are several potential areas for automation at the studied remanufacturing companies with different levels of HRC (see [46]). In general, the main potential areas for automation were found to be in disassembly, cleaning and reassembly. Disassembly and reassembly can be seen as two sides of the same coin. Through the interviews in this study, inspection and reprocessing were also added to the potential areas for automation (see Table 2); however, both are completely dependent on the type of product, inspection and reprocessing. For instance, reprocessing may refer to the repair and exchange of faulty components or to refilling.

The main issues with incentivizing placing automation in these remanufacturing processes were the work environment issue, efficiency and quality. The work environment issue can be exemplified with the disassembly, cleaning and refilling (reprocess) of toner cartridges in company B, which are dirty and noisy. The retrieved cartridges for remanufacturing still contain some (black) toner. Toner powder is very light, so it spreads very easily and attaches to most things it comes in contact with. Therefore, operators that disassemble, clean and refill (reprocess) retrieved cartridges are often adversely affected by irritated eyes and throats. In addition, this remanufacturing process is equipped with large ventilation systems and compressed air, which make it very noisy and negatively affects the operators' work environment. The efficiency issue can be exemplified by the reprocessing of retrieved laptops in company A, which includes placing, connecting and setting up laptops for the data erasing, disconnecting, sorting, classification and destruction of non-erasable hard disc drives. These remanufacturing processes at company A are time-consuming, boring and repetitive for operators but require operators to pay complete attention to hundreds of laptops that are data erased. The quality issue can be exemplified by cleaning processes at companies B and C, where components are cleaned to the operators' individual subjective standards of cleanliness and discernment, i.e., there is no standard procedure specifying the process and extent for cleaning products, but more of a subjective inspection and cleaning based on the operators' experience, acumen and personal ideals for approval.

Industrial robots were traditionally set up in safety cells for repetitive, tedious tasks and heavy lifting operations in a difficult working environment to provide consistent quality and efficiency with long cycle times [50,51]. These traditional industrial robots in safety cells have basically fixed output with a given number of operations, because with a certain determined input, they follow the same pattern of known parameters for quality, positioning and number of products. However, in repair and remanufacturing processes, such determined input parameters are often nonexistent or unclear from the very beginning, e.g., one retrieved product can be dirty, rusty or broken while the other 
is fine. Therefore, in the EEE industry, repair and remanufacturing tasks are to a very large extent carried out by humans, who can identify uncertainties and make different decisions based on the retrieved products' conditions. Two of the biggest challenges of the studied remanufacturing processes are diverse quality and low volumes of retrieved products that require efficiency and flexibility in the automation solutions, which can be supported by a HRC layout. With HRC, robot advantages such as endurance, efficiency and accuracy are combined with human trump cards, namely, intuition, flexibility and problem solving [6]. With an understanding of how to design an HRC layout for disassembly [45], including risk assessment and management [44], flexibility and efficiency issues in the remanufacturing processes [40] can already be addressed in the product design phase. An understanding of remanufacturing and its automation requirements that is acknowledged in the product design and development can largely contribute to a more cost-efficient overall business solution.

Using the theoretical background with regard to automation and HRC levels, the empirical study at the remanufacturing companies, the authors' previous experiences with both aspects of automation and remanufacturing, and an iterative dialog with the industrial partners regarding increased automation within their remanufacturing companies, the potential areas for automation at the studied remanufacturing companies can be summarized in Table 5. As mentioned earlier, automation in this study mainly includes robotization and the utilization of a robot arm to facilitate the remanufacturing processes, even though automation in general refers to any technological improvement in carrying out the processes with reduced human intervention (e.g., using robots, automated guided vehicles (AGVs), computerization, software, etc.). Therefore, software upgrading for the faster inspection of incoming products and data erasing in Table 5 cannot make use of a robot arm/HRC, but they were still identified as a potential area for automation. Furthermore, the identified potential areas for automation reflect the possibility of applications in the existing production system where the operators might interact with a robot differently.

Table 5. The identified potential for automation in different remanufacturing processes at the case companies with various levels of HRC.

\begin{tabular}{|c|c|c|c|}
\hline Remanufacturing Process & Company A & Company B & Company C \\
\hline Inspection & $\begin{array}{l}\text { Software upgrade for faster } \\
\text { inspection (N/A) }\end{array}$ & & \\
\hline Disassembly & $\begin{array}{l}\text { Disconnecting laptops } \\
\text { (Coexistence) }\end{array}$ & $\begin{array}{c}\text { Dismantling toner cartridges } \\
\text { (Synchronized) }\end{array}$ & $\begin{array}{l}\text { Removing sealant } \\
\text { (Cell) }\end{array}$ \\
\hline Cleaning & & $\begin{array}{l}\text { Removing toner } \\
\text { (Synchronized) }\end{array}$ & $\begin{array}{l}\text { Cleaning the core } \\
\text { (Cooperation) }\end{array}$ \\
\hline Reprocessing & $\begin{array}{l}\text { Data erasing } \\
(\mathrm{N} / \mathrm{A})\end{array}$ & $\begin{array}{c}\text { Refilling } \\
\text { (Coexistence) }\end{array}$ & $\begin{array}{l}\text { Exchange of components } \\
\text { (Coexistence) }\end{array}$ \\
\hline Reassembly & $\begin{array}{l}\text { Connecting laptops for data } \\
\text { erasing (Coexistence) }\end{array}$ & & $\begin{array}{c}\text { Sealing } \\
\text { (Coexistence) }\end{array}$ \\
\hline Testing & & & \\
\hline
\end{tabular}

\subsection{Connecting Automation to Product Design for Remanufacturing Processes}

This section discusses product design guidelines that are essential for future remanufacturing, i.e., those guidelines that are color-coded in red or yellow in Figure 4, while the rest of the guidelines color-coded in green or blue are either already at a sufficient level of deployment or not important and not to be discussed further. This section discusses only those product design guidelines that will facilitate remanufacturing in the future, and we explain how these guidelines can also influence automated remanufacturing. Table 6 summarizes the results achieved from Sections 5.1 and 5.2. It shows 
- Potential areas for automation in each remanufacturing process (shown in gray cells with $\checkmark$ )

- Potential product design improvements in each remanufacturing process (imported guideline numbers and colors from Figure 4)

Table 6. Combining the potential areas for automation and the product design guidelines for each remanufacturing process. Gray cells with $\checkmark$ represent potential areas for automation; red cells represent vital and imperative product design changes to facilitate remanufacturing; yellow cells represent potential areas for product design improvements to facilitate remanufacturing; numbers represent the guidelines from Figure 4.

\begin{tabular}{|c|c|c|c|}
\hline \multirow[b]{2}{*}{ Remanufacturing Processes } & \multicolumn{2}{|c|}{ Product Design Facilitation via Guidelines (Section 5.1) } & \multirow{2}{*}{$\begin{array}{c}\text { Automation Facilitation } \\
\text { (Section 5.2) }\end{array}$} \\
\hline & $\begin{array}{l}\text { Vital and Imperative Design } \\
\text { Changes }\end{array}$ & $\begin{array}{l}\text { Potential Design } \\
\text { Improvements }\end{array}$ & \\
\hline Inspection & 2,15 & 20 & $\checkmark$ \\
\hline Disassembly & 15 & $6,7,8,10$ & $\checkmark$ \\
\hline Cleaning & 15 & 3 & $\checkmark$ \\
\hline Reprocess & 13,15 & $1,7,8,9,10,20,21,22$ & $\checkmark$ \\
\hline Reassembly & 15 & $6,7,8,10$ & $\checkmark$ \\
\hline Testing & & & \\
\hline
\end{tabular}

Looking at Table 6, both product design and automation can facilitate almost all remanufacturing processes except testing, although the automation-induced facilitation of inspection is not connected to HRC but to software upgrading.

Providing repair manuals and documentation (guideline 15, marked red in Table 6) on how to disassemble and assemble back a product and its components in a nondestructive and time-efficient manner, how to take care of products such as cleaning and how to repair the product (e.g., indicating the exchangeable component or parts that usually wear out) all facilitate manual remanufacturing. However, the same manuals and documentation can be used for automated remanufacturing. For example, a manual can indicate which part of the product usually wears out and needs to be changed. As a result, when setting up an automation and designing the automated remanufacturing using a robot arm, it can be easily indicated from which side the product needs to be opened. Hence, the robot arm should grip the product from the opposite side. These manuals will be helpful when designing automation and how a robot should function (grip, repair, dismantle, etc.) in remanufacturing processes.

Providing information (guideline 13, marked red in Table 6) about the product's material content, tolerances, age, the number of times it has been recycled, the additives used or generally any information regarding its material characteristics and properties can be helpful for manual and automated remanufacturing. For example, how much pressure can a robot apply to grip the product? In addition, if a product contains hazardous materials or chemicals, using a robot instead of a human would be beneficial for health and safety reasons. Furthermore, in automated remanufacturing, where faulty components can be automatically exchanged with a robot arm, it would be much easier to plan automated material and component separation into different material fractions.

Product design can influence the ease of inspection (guideline 2, marked red in Table 6) in remanufacturing processes. However, according to our interviewees, automation in the form of HRCs is of less help here. However, automation in the form of software upgrades for the faster inspection of EEE is fruitful. In addition, our studied remanufacturing companies currently rely on subjective evaluation (visual eye inspection) and personal judgment. Therefore, with their product type and huge variety in models and brands, it would be advantageous to have a large digital database for different evaluation protocols. Furthermore, with the standardization of components and tools (guidelines 7 and 8) in the future, automated inspection would significantly benefit from a standard evaluation protocol that fits all product types, brands, and models. 
In lean manufacturing, automation for similar and repetitive jobs can increase efficiency and productivity and reduce lead time and costs. Lean automated manufacturing requires minimum disturbances, delays and stops with a high availability of tools and parts to have a continuous and one-piece flow [52]. Similar to automation in lean manufacturing, automated remanufacturing is also highly dependent on continuous and one-piece flow with as few disturbances, delays and stops as possible. However, unlike manufacturing, remanufacturing is usually carried out for several different product models and brands with different qualities, sizes, shapes, materials, characteristics, and designs (even within the same brand). Consequently, to ease automated remanufacturing (which in turn increases remanufacturing efficiency, productivity and reduces lead time and cost), disturbances, delays and stops need to be eliminated. One of the main reasons for such disturbances is the setup time required for different remanufactured products where remanufacturing tools need to be changed. For instance, the way that remanufactured products are disassembled, repaired, and reassembled differs from one product to another. However, this diversity, which brings disruptions, can be greatly reduced if the products and components are standardized. As a result, setup times will be reduced, and remanufacturing tools and equipment do not necessarily need to be changed. Therefore, designing products with standard components, tools, fasteners and connectors across different models and brands is essential for automated remanufacturing. Guidelines 6, 7, 8, 9 and 10 (marked yellow in Table 6) closely refer to such aspects in lean philosophy [52], where standardization can (1) raise the (re)manufacturing line to a level of efficiency that allows the operator to simply load the part and move on to the next operation (Chaku-Chaku), (2) smooth the automatic unloading and orientation of the workpiece from one operation or process, providing the proper state for the next workpiece to be loaded (Hanedashi) and (3) smooth (re)manufacturing flow with balancing processes and the maximum utilization of available time (Nagara).

To ease automation in remanufacturing processes, accessibility (guideline 1, marked yellow in Table 6) plays an important role. Components to be exchanged or parts that are subject to stress, wear, corrosion, stain, breaking or failing easily should be marked, easy to recognize and easy to access, preferably from one side. Likewise, it is equally important for automated remanufacturing that a product is designed in a way that makes the cleaning (guideline 3, marked yellow in Table 6) process much easier. For example, the interior parts of a product can be designed in shapes and forms that facilitate automated cleaning with a robot arm, and areas in which dirt might collect such as holes, nooks, grooves, sharp edges and thresholds must be avoided.

Digitalization (guideline 20, marked yellow in Table 6) in any form, such as IoT, ICT or RFID tags, can facilitate automated remanufacturing since the product and remanufacturing processes can communicate. For instance, a broken product can communicate that only one specific component needs to be replaced, and an automated remanufacturing robot arm will grab and position a product in a way such that the exchanging component can be easily replaced from a correct side or, depending on the problem, that the right reprocessing step will generally be carried out, e.g., refill, repair, exchange, etc.

Design guidelines related to using renewable, recycled, and recyclable materials (guidelines 21 and 22, marked yellow in Table 6) are less connected to automation, despite what our empirical results represent in Table 6 . Nevertheless, material selection is also very important for any circulation scenario. Since a product or component, even those designed for remanufacturing, in the end becomes so worn out that it cannot be used further, select materials that can then be recycled into new materials after many lifecycles are of importance. One aspect of material selection connected to automation in remanufacturing is the characteristics of the material, which can provide a better grip for automated robot arms. This aspect needs to be further investigated. 


\section{Conclusions and Future Work}

Most existing products and components that are currently being traded or used in the market have not been designed for circulation of any sort (e.g., remanufacturing), whereas achieving a circular economy is greatly dependent on the very beginning stage of the product lifecycle, namely, product design and development (e.g., the ease of disassembling components and the exchange of faulty components). In addition, despite the technological advancements within automation, the usage of robots and HRC technologies in remanufacturing processes is still generally under-researched, although some attempts have been made in remanufacturing EEE. This paper, within the area of the circular economy, connects the three areas of remanufacturing, product design and automation and aims to investigate the connection of product design to automation in remanufacturing processes. Through more remanufacturing, products will be kept in use for a longer time (product lifecycle extension) and added value will be retained as much as possible. Consequently, resource (material and energy) consumption in the transportation and production of the new product is saved, new resource extraction is avoided, and materials and components will be circulated in closed loops.

To achieve our research aim, three research questions were formulated: (1) how product design can support remanufacturing, (2) how automation can support remanufacturing processes and (3) how future products should be designed to facilitate automated remanufacturing. The specific answers to these questions were answered in Sections 5.1-5.3, respectively. In accordance with previous research, this paper also confirms that product design and automation can positively influence and facilitate remanufacturing processes; however, our empirical study specified the remanufacturing processes and their connection to specific design guidelines. In Section 5.1, it was argued that several product design guidelines (color-coded in red and yellow in Figure 4 and Table 6) will facilitate remanufacturing in the future. Section 5.2 discusses potential areas for automation in our studied companies with some examples. It was also highlighted that the main incentive for having automation in place for these remanufacturing processes was mainly related to the work environment, efficiency, and quality. Furthermore, Section 5.3 indicates how some product design guidelines (yellow and red color-coded) can facilitate automated remanufacturing processes. For instance, the standardization of components, fasteners and remanufacturing tools across different models and brands can facilitate automated remanufacturing, and products can easily and nondestructively be disassembled by a robot.

The study presented in this paper included remanufacturing companies located in Sweden with sales and marketing around the globe. Two of them have contracts with OEMs. Future studies might investigate how contracted remanufacturers can affect product design and development at OEMs. There is also a time gap where remanufactured products are on average 5-7 years old and the current design specification has completely changed. Hence, it would be interesting to research how a remanufacturer (independent or contracted) that remanufactures 5-7-year-old products can influence current product design processes at OEMs. In addition, the result achieved here is mainly based on remanufacturers' perspectives on product design. Future work might study OEMs' perspectives on design for remanufacturing and how they look back and learn from previous products and current remanufacturing processes. Therefore, the inclusion of an OEM that has its own remanufacturing processes and flows is of much interest. Additionally, although our empirical results linked using material selection guidelines for automated remanufacturing, we see a loose connection. This area needs to be further investigated in detail. Likewise, the possibilities that current and future digitalization technologies provide for automated remanufacturing in combination with product design (see e.g., Subranmoniam et al. [53] need further investigation. Furthermore, this study is mainly aimed at the design perspective and how design guidelines can affect automated remanufacturing. These design guidelines can be further combined and cross-checked with automation guidelines and requirements. Moreover, our performed study is on the EEE remanufacturing industry, and future studies might include other types of industries. 
Author Contributions: S.S. contributed to the data collection and analysis, the literature and empirical studies, the discussions and conclusion and the writing. K.J. and E.S. contributed to the data collection, analysis, writing and proofreading. All authors have read and agreed to the published version of the manuscript.

Funding: This research was part of research project ARR (Automation in Repair and Remanufacturing). ARR project is part of the Produktion2030 programme (grant number: 2018-01591), which is funded by the Swedish Government Innovation Agency (VINNOVA), Formas and the Swedish Energy Agency. RISE also acknowledges the funding received from the XPRES initiative.

Institutional Review Board Statement: Not applicable.

Informed Consent Statement: Not applicable.

Data Availability Statement: Not applicable.

Acknowledgments: This paper is one of the outcomes of the ARR research project, and we would like to thank the companies participating in the ARR project and the reviewers whose thoughtful feedback aided the development of this work.

Conflicts of Interest: The authors declare no conflict of interest.

\section{References}

1. Prendeville, S.; Bocken, N. Design for Remanufacturing and Circular Business Models. In Sustainability through Innovation in Product Life Cycle Design; Matsumoto, M., Masui, K., Fukushige, S., Kondoh, S., Eds.; Springer: Singapore, 2017; pp. 269-283.

2. Hatcher, G.D.; Ijomah, W.L.; Windmill, J.F.C. Design for remanufacture: A literature review and future research needs. J. Clean. Prod. 2011, 19, 2004-2014. [CrossRef]

3. Tukker, A. Product services for a resource-efficient and circular economy-A review. J. Clean. Prod. 2015, 97, 76-91. [CrossRef]

4. Bakker, C.; Wang, F.; Huisman, J.; Hollander, M.D. Products that go round: Exploring product life extension through design. J. Clean. Prod. 2014, 69, 10-16. [CrossRef]

5. Sakao, T.; Sundin, E. How to improve remanufacturing?-A systematic analysis of practices and theories. J. Manuf. Sci. Eng. 2019, 141, 141. [CrossRef]

6. Wang, L.; Gao, R.; Váncza, J.; Krüger, J.; Wang, X.; Makris, S.; Chryssolouris, G. Symbiotic human-robot collaborative assembly. CIRP Ann. 2019, 68, 701-726. [CrossRef]

7. Sundin, E.; Backman, B.; Johansen, K.; Hochwallner, M.; Landscheidt, S.; Shahbazi, S. Automation Potential in the Remanufacturing of Electric and Electronic Equipment (EEE). In Proceedings of the 9th Swedish Production Symposium, Jönköping, Sweden, 7-8 October 2020.

8. Ellen MacArthur Foundation. Towards the Circular Economy. Economic and Business Rationale for an Accelerated Transitio-Executive Summary; Ellen MacArthur Foundation: Cowes, UK, 2012.

9. The European Commission. Closing the Loop-An EU Action Plan for the Circular Economy COM/2015/0614; The European Commission: Brussels, Belgium, 2015.

10. Pigosso, D.; McAloone, T. How can design science contribute to a circular economy? In Proceedings of the International Conference on Engineering Design ICED, Vancouver, BC, Canada, 21-25 August 2017.

11. Sundin, E. Product and Process Design for Successful Remanufacturing; Linköping University Electronic Press: Linköping, Sweden, 2004.

12. Kerr, W.; Ryan, C. Eco-efficiency gains from remanufacturing: A case study of photocopier remanufacturing at Fuji Xerox Australia. J. Clean. Prod. 2001, 9, 75-81. [CrossRef]

13. Nasr, N.; Russell, J. UNEP International Resource Panel, Re-Defining Value: The Manufacturing Revolution-Remanufacturing, Refurbishment, Repair and Direct Reuse in the Circular Economy. IRP Reports. Available online: https:/ /www.resourcepanel. org/reports / re-defining-value-manufacturing-revolution (accessed on 20 December 2018).

14. Kernbaum, S.; Franke, C.; Seliger, G. Flat screen monitor disassembly and testing for remanufacturing. Int. J. Sustain. Manuf. 2008, 1, 347. [CrossRef]

15. Shahbazi, S.; Jönbrink, A.K. Design Guidelines to Develop Circular Products: Action Research on Nordic Industry. Sustainability 2020, 12, 3679. [CrossRef]

16. Yin, R.K. Case Study Research: Design and Methods, 5th ed.; SAGE Publications, Inc: Thousand Oaks, CA, USA, 2014.

17. Miles, M.B.; Huberman, A.M. Qualitative Data Analysis: An Expanded Sourcebook; SAGE Publications: Thousand Oaks, CA, USA, 1994.

18. Blomsma, F.; Pieroni, M.; Kravchenko, M.; Pigosso, D.C.; Hildenbrand, J.; Kristinsdottir, A.R.; Kristoffersen, E.; Shahbazi, S.; Nielsen, K.; Jönbrink, A.K.; et al. Developing a circular strategies framework for manufacturing companies to support circular economy oriented innovation. J. Clean. Prod. 2019, 241, 118271. [CrossRef] 
19. Östlin, J. On Remanufacturing Systems: Analysing and Managing Material Flows and Remanufacturing Processes. In Linköping Studies in Science and Technology; Production Systems, Department of Management and Engineering, Linköping University: Linköping, Sweden, 2008.

20. Lindkvist Haziri, L.; Sundin, E. Supporting design for remanufacturing-A framework for implementing information feedback from remanufacturing to product design. J. Remanuf. 2020, 10, 57-76. [CrossRef]

21. Shao, J.; Huang, S.; Lemus-Aguilar, I.; Ünal, E. Circular business models generation for automobile remanufacturing industry in China. J. Manuf. Technol. Manag. 2019, 31, 542-571. [CrossRef]

22. Wei, S.; Cheng, D.; Sundin, E.; Tang, O. Motives and barriers of the remanufacturing industry in China. J. Clean. Prod. 2015, 94, 340-351. [CrossRef]

23. Gunasekara, H.; Gamage, J.; Punchihewa, H. Remanufacture for sustainability: Barriers and solutions to promote automotive remanufacturing. Procedia Manuf. 2020, 43, 606-613. [CrossRef]

24. Shahbazi, S.; Wiktorsson, M.; Kurdve, M.; Jönsson, C.; Bjelkemyr, M. Material efficiency in manufacturing: Swedish evidence on potential, barriers and strategies. J. Clean. Prod. 2016, 127, 438-450. [CrossRef]

25. Kurilova-Palisaitiene, J.; Sundin, E.; Poksinska, B. Remanufacturing challenges and possible lean improvements. J. Clean. Prod. 2018, 172, 3225-3236. [CrossRef]

26. Lee, H.M. An Ontology-Based Product Design Adviser for Assessing End-of-Life (EoL) Performance. Ph.D. Thesis, Nanyang Technological University, Singapore, 2008.

27. Kuo, T.-C.; Huang, S.H.; Zhang, H.-C. Design for manufacture and design for ' $X$ ': Concepts, applications, and perspectives. Comput. Ind. Eng. 2002, 41, 241-260. [CrossRef]

28. Go, T.; Wahab, D.A.; Hishamuddin, H. Multiple generation life-cycles for product sustainability: The way forward. J. Clean. Prod. 2015, 95, 16-29. [CrossRef]

29. Vezzoli, C.; Manzini, E. Design for Environmental Sustainability; Springer: London, UK, 2008.

30. Branowski, B.; Zabłocki, M.; Sydor, M. The Material Indices Method in the Sustainable Engineering Design Process: A Review. Sustainability 2019, 11, 5465. [CrossRef]

31. Battaïa, O.; Dolgui, A.; Heragu, S.S.; Meerkov, S.M.; Tiwari, M.K. Design for manufacturing and assembly/disassembly: Joint design of products and production systems. Int. J. Prod. Res. 2018, 56, 7181-7189. [CrossRef]

32. Soh, S.; Ong, S.; Nee, A. Design for assembly and disassembly for remanufacturing. Assem. Autom. 2016, 36, 12-24. [CrossRef]

33. Boks, C.; McAloone, T.C. Transitions in sustainable product design research. Int. J. Prod. Dev. 2009, 9, 429. [CrossRef]

34. Knight, P.; Jenkins, J.O. Adopting and applying eco-design techniques: A practitioners perspective. J. Clean. Prod. 2009, 17, 549-558. [CrossRef]

35. Rodrigues, V.P.; Pigosso, D.C.A.; McAloone, T.C. Measuring the implementation of ecodesign management practices: A review and consolidation of process-oriented performance indicators. J. Clean. Prod. 2017, 156, 293-309. [CrossRef]

36. Hultgren, N. Guidelines and Design Strategies for Improved Product Recyclability-How to Increase the Recyclability of Consumer Electronics and Domestic Appliances through Product Design. Master's Thesis, Chalmers University of Technology, Gothenburg, Sweden, 2012.

37. Hu, Q.; Peng, Y.; Guo, C.; Cai, D.; Su, P. Dynamic Incentive Mechanism Design for Recycling Construction and Demolition Waste under Dual Information Asymmetry. Sustainability 2019, 11, 2943. [CrossRef]

38. Lindkvist Haziri, L.; Sundin, E.; Sakao, T. Feedback from Remanufacturing: Its Unexploited Potential to Improve Future Product Design. Sustainability 2019, 11, 4037. [CrossRef]

39. Sundin, E.; Elo, K.; Lee, H.M. Design for automatic end-of-life processes. Assem. Autom. 2012, 32, 389-398. [CrossRef]

40. Browne, J.; Dubois, D.; Rathmill, K.; Sethi, S.P.; Stecke, K.E. Classification of flexible manufacturing systems. FMS Mag. 1984, 2, 114-117.

41. Zheng, C.; Qin, X.; Eynard, B.; Bai, J.; Li, J.; Zhang, Y. SME-oriented flexible design approach for robotic manufacturing systems. J. Manuf. Syst. 2019, 53, 62-74. [CrossRef]

42. Vincent, L.W.H.; Ponnambalam, S.; Kanagaraj, G. Differential evolution variants to schedule flexible assembly lines. J. Intell. Manuf. 2014, 25, 739-753. [CrossRef]

43. Huang, J.; Pham, D.T.; Li, R.; Qu, M.; Wang, Y.; Kerin, M.; Su, S.; Ji, C.; Mahomed, O.; Khalil, R.; et al. An experimental human-robot collaborative disassembly cell. Comput. Ind. Eng. 2021, 155, 107189. [CrossRef]

44. Gopinath, V.; Johansen, K. Understanding situational and mode awareness for safe human-robot collaboration: Case studies on assembly applications. Prod. Eng. 2019, 13, 1-9. [CrossRef]

45. Wegener, K.; Chen, W.H.; Dietrich, F.; Dröder, K.; Kara, S. Robot assisted disassembly for the recycling of electric vehicle batteries. Procedia Cirp 2015, 29, 716-721. [CrossRef]

46. Bauer, W.; Bauer, W.; Bender, M.; Braun, M.; Rally, P.; Scholtz, O. Lightweight Robots in Manual Assembly—Best to Start Simply; Frauenhofer-Institut für Arbeitswirtschaft und Organisation IAO: Stuttgart, Germany, 2016.

47. Pigosso, D.C.; Zanette, E.T.; Filho, A.G.; Ometto, A.R.; Rozenfeld, H. Ecodesign methods focused on remanufacturing. J. Clean. Prod. 2010, 18, 21-31. [CrossRef]

48. Sundin, E.; Östlin, J.; Öhrwall Rönnbäck, A.; Lindahl, M.; Sandström, G. Remanufacturing of products used in product service system offerings. In Manufacturing Systems and Technologies for the New Frontier; Springer: Berlin/Heidelberg, Germany, 2008; pp. 537-542. 
49. Charter, M.; Gray, C. Remanufacturing and product design. Int. J. Prod. Dev. 2008, 6, 375-392. [CrossRef]

50. ISO. 10218-1/2:2011, Robots and Robotic Devices—Safety Requirements for Industrial Robots_Part 1: Robots/Part 2: Robot Systems and Integration; International Organization for Standardization: Geneva, Switzerland, 2011.

51. Wilson, M. Implementation of Robot Systems: An Introduction to Robotics, Automation, and Successful Systems Integration in Manufacturing; Butterworth-Heinemann: Oxford, UK, 2014.

52. Liker, J. The Toyota Way: 14 Management Principles from the World's Greatest Manufacturer: 14 Management Principles from the World's Greatest Manufacturer; Mcgraw-Hill: New York, NY, USA, 2003.

53. Subramoniam, R.; Sundin, E.; Subramoniam, S.; Huisingh, D. Riding the Digital Product Life Cycle Waves towards a Circular Economy. Sustainability 2021, 13, 8960. 